\title{
OPEN Orbital controls on eastern African hydroclimate in the Pleistocene
}

\begin{abstract}
Rachel L. Lupien ${ }^{1,2 \bowtie}$, James M. Russell ${ }^{1}$, Emma J. Pearson ${ }^{3}$, Isla S. Castañeda ${ }^{4}$, Asfawossen Asrat ${ }^{5,6}$, Verena Foerster ${ }^{7}$, Henry F. Lamb ${ }^{8,9}$, Helen M. Roberts ${ }^{8}$, Frank Schäbitz ${ }^{7}$, Martin H. Trauth ${ }^{10}$, Catherine C. Beck ${ }^{11}$, Craig S. Feibel ${ }^{12}$ \& Andrew S. Cohen ${ }^{13}$

Understanding eastern African paleoclimate is critical for contextualizing early human evolution, adaptation, and dispersal, yet Pleistocene climate of this region and its governing mechanisms remain poorly understood due to the lack of long, orbitally-resolved, terrestrial paleoclimate records. Here we present leaf wax hydrogen isotope records of rainfall from paleolake sediment cores from key time windows that resolve long-term trends, variations, and high-latitude effects on tropical African precipitation. Eastern African rainfall was dominantly controlled by variations in low-latitude summer insolation during most of the early and middle Pleistocene, with little evidence that glacialinterglacial cycles impacted rainfall until the late Pleistocene. We observe the influence of highlatitude-driven climate processes emerging from the last interglacial (Marine Isotope Stage 5) to the present, an interval when glacial-interglacial cycles were strong and insolation forcing was weak. Our results demonstrate a variable response of eastern African rainfall to low-latitude insolation forcing and high-latitude-driven climate change, likely related to the relative strengths of these forcings through time and a threshold in monsoon sensitivity. We observe little difference in mean rainfall between the early, middle, and late Pleistocene, which suggests that orbitally-driven climate variations likely played a more significant role than gradual change in the relationship between early humans and their environment.
\end{abstract}

Understanding changes in eastern African hydroclimate during the Pleistocene is central to investigations of how humans evolved in a variable environment ${ }^{1-8}$. Over the Pleistocene, eastern African rainfall is thought to have undergone both secular and periodic changes driven by global cooling, evolving tropical sea surface temperature (SST) gradients, low-latitude insolation forcing, and glacial-interglacial cycles ${ }^{3,9-17}$. Each of these forcings has specific implications for the nature and timing of eastern African rainfall changes, which in turn yield predictions for the environmental changes experienced by our hominin ancestors. However, a lack of long datasets capable of resolving orbital cycles $\left(10^{3}-10^{5}\right.$ years $)$ limits our understanding of the relative influences of global climate forcings on the Pleistocene evolution of tropical eastern African rainfall, as well as the effects of paleoenvironmental change on early humans.

Varying seasonal insolation, controlled by the Earth's orbital precession and eccentricity, causes changes in the differential heating of the African continent and oceans, driving fluctuations in the East African Monsoon strength $^{18,19} .21-\mathrm{kyr}$ cycles in monsoonal rainfall that result from this process are well-documented in eastern African climate records $s^{9,11,20-26}$, and their varying amplitude has been argued to have played a pivotal role in human evolution ${ }^{6,27}$. Coupled changes in the Earth's carbon cycle and atmospheric greenhouse gas concentrations, global temperatures, and high-latitude glacial-interglacial cycles are also thought to play a critical role in eastern African climate evolution ${ }^{3,4,28}$, and long-term variations in these processes may have contributed to

${ }^{1}$ Department of Earth, Environmental, and Planetary Sciences, Brown University, Providence, RI 02912, USA. ${ }^{2}$ Biology and Paleo Environment, Lamont-Doherty Earth Observatory of Columbia University, Palisades, NY 10964, USA. ${ }^{3}$ School of Geography, Politics \& Sociology, Newcastle University, Newcastle Upon Tyne NE1 7RU, UK. ${ }^{4}$ Department of Geosciences, University of Massachusetts Amherst, Amherst, MA 01003, USA. ${ }^{5}$ Department of Mining and Geological Engineering, Botswana International University of Science and Technology, Private Bag 16, Palapye, Botswana. ${ }^{6}$ School of Earth Science, Addis Ababa University, Addis Ababa, Ethiopia. ${ }^{7}$ Institute for Geography Education, University of Cologne, 50931 Cologne, Germany. ${ }^{8}$ Department of Geography and Earth Sciences, Aberystwyth University, Aberystwyth SY23 3DB, UK. 'BBotany Department, Trinity College Dublin, Dublin 2, Ireland. ${ }^{10}$ Institute of Geosciences, University of Potsdam, 14476 Potsdam, Germany. ${ }^{11}$ Geosciences Department, Hamilton College, Clinton, NY 13323, USA. ${ }^{12}$ Department of Earth and Planetary Sciences, Rutgers University, Piscataway, NJ 08854, USA. ${ }^{13}$ Department of Geosciences, University of Arizona, Tucson, AZ 85721, USA. ${ }^{\boxplus}$ email: rlupien@Ideo.columbia.edu 


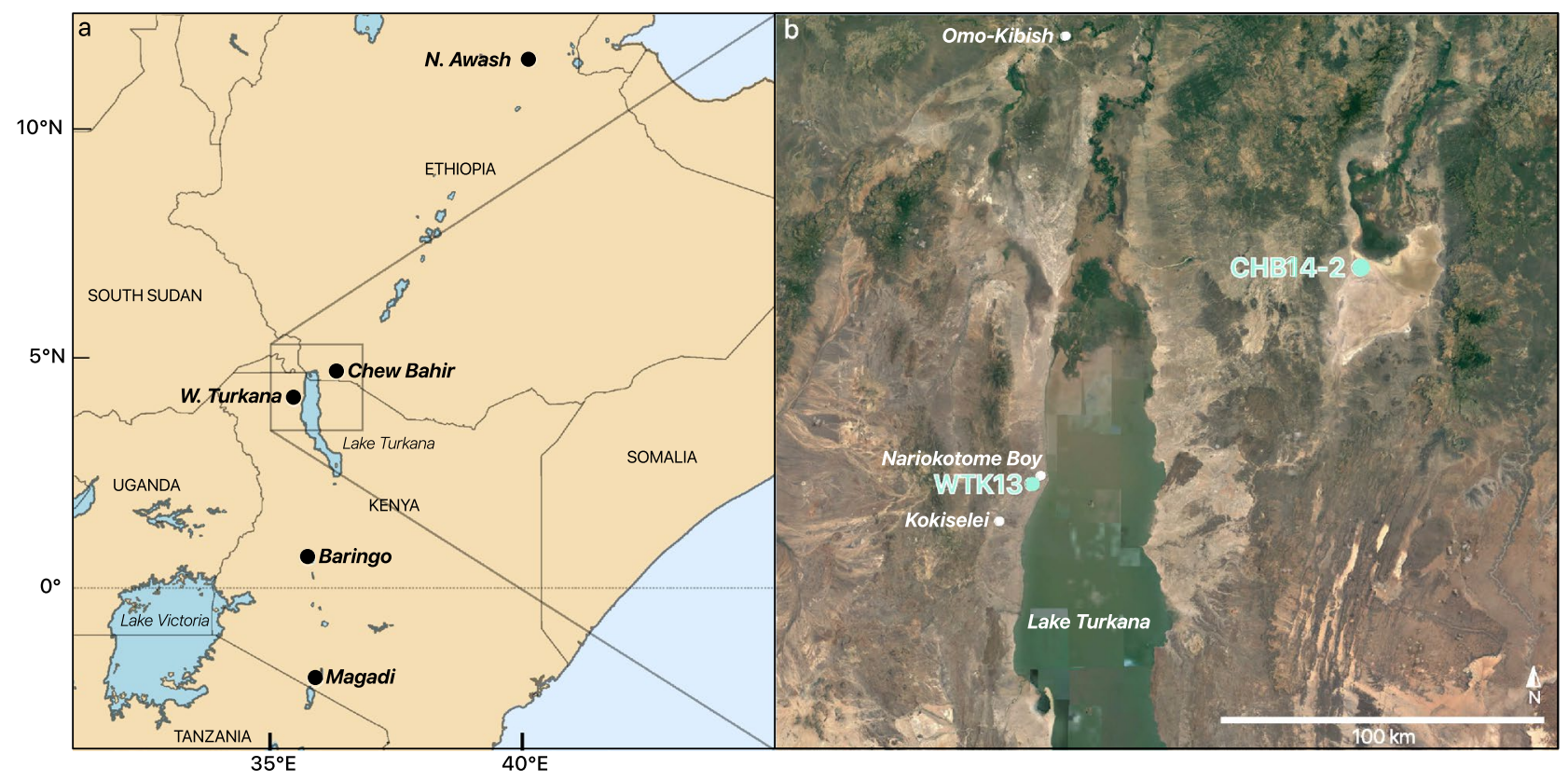

Figure 1. (a) East African Rift System study area map, including HSPDP sites and major rift lakes, generated in Python 3.8; (b) Ethiopian and Kenyan locations of the two paleolake sediment drill cores, WTK13 and CHB142, included in this study with Omo-Kibish and Nariokotome Boy hominin sites and the Kokiselei site of the first evidence for Acheulean hand axes ${ }^{48}$. Map generated in Google Earth Pro 7.3.3.

the development of bipedalism and other traits ${ }^{29}$. For instance, soil carbonate isotope $\left(\delta^{18} \mathrm{O}_{\mathrm{sc}}\right)$ records indicate gradual drying in northern and tropical Africa ${ }^{30,31}$, attributed to global cooling and ice-volume growth through the Pleistocene. Records of dust from the eastern Atlantic and the Mediterranean and Arabian Seas suggest transitions from 21- to 41- to 100-kyr periodicity over the Plio-Pleistocene, with shifts toward drier conditions and increased variability starting between 3500 and $2500 \mathrm{ka}$ (onset and gradual intensification of Northern Hemisphere glaciation) and at $1000 \mathrm{ka}^{3,4}$ (mid-Pleistocene Transition, MPT), matching transitions in the marine oxygen isotopic record of global ice volume $\mathrm{e}^{32}$. However, recent accumulation rate corrections $\mathrm{s}^{33}$ and time series analyses ${ }^{12}$ suggest different timings of aridification and a stronger influence of low-latitude insolation. Furthermore, strengthening of zonal SST gradients in the tropical Pacific beginning at $\sim 1700 \mathrm{ka}^{34}$ is thought to have weakened convection over eastern Africa, contributing to regional drying ${ }^{16}$. To date, despite the paleoanthropological significance of eastern Africa, the relative importance of low- and high-latitude climate forcings on the region's rainfall history remain poorly constrained.

The Hominin Sites and Paleolakes Drilling Project (HSPDP) recovered sediment drill-cores that record the environmental history of key hominin fossil locales in Ethiopia and Kenya ${ }^{35-37}$. The cores allow us to develop and compare multiple long, high-resolution records of regional hydroclimate within a set of key time windows to elucidate the forcings and mechanisms of climate change in the region. Here we present a new record of the hydrogen isotopic composition of precipitation $\left(\delta \mathrm{D}_{\text {precip }}\right)$ from compound-specific analyses of terrestrial leaf waxes - a novel and powerful proxy for processes related to rainfall ${ }^{38}$ - preserved in middle to late Pleistocene sediments from the Chew Bahir Basin, Ethiopia. This is compared with an existing record of the early Pleistocene from the adjacent Omo-Turkana Basin $^{24}$ to evaluate changing trends and rhythms in regional hydroclimate, as well as the relative influences of high- and low-latitude forcings during intervals of the early and middle to late Pleistocene.

The HSPDP core locations lie in the East African Rift System (Fig. 1a), host to many famous hominin fossil $\operatorname{sites}^{39-41}$. We generated a new hydroclimate record derived from the hydrogen isotopic composition of terrestrial leaf waxes $\left(\delta D_{\text {wax }}\right)$ preserved in paleolake deposits from Chew Bahir, southern Ethiopia (duplicate drill cores HSPDP-CHB14-2A and -2B merged to composite core ${ }^{42,43}$, hereafter CHB14-2). Coring site CHB14-2 $\left(4^{\circ} 45^{\prime} 40^{\prime \prime} \mathrm{N}, 36^{\circ} 46^{\prime} 00^{\prime \prime} \mathrm{E}\right)$ is located in the Chew Bahir Basin, just northeast of the Omo-Turkana Basin (Fig. 1b). Today, the southern part of the basin floor is mostly occupied by a saline mudflat. The composite core extends from $\sim 620 \mathrm{ka}$ to present with age constraints based on ${ }^{40} \mathrm{Ar} /{ }^{39} \mathrm{Ar}$ dating of tephra, optically stimulated luminescence (OSL), radiocarbon dating, and tephrostratigraphic correlations ${ }^{44}$. We analyzed waxes spanning the interval from $\sim 250 \mathrm{ka}$ to present-day and synthesized this new dataset with a published record from West Turkana, Kenya ${ }^{24,45}$ (1900-1400 ka; HSPDP-WTK13-1A, hereafter WTK13) located $100 \mathrm{~km}$ from CHB14-2 $\left(4^{\circ} 6^{\prime} 35^{\prime \prime} \mathrm{N}, 35^{\circ} 52^{\prime} 18^{\prime \prime} \mathrm{E}\right)$. The age model for WTK13 is based on tephrochronology and magnetostratigraphy and includes very conservative tuning of $\delta \mathrm{D}_{\text {precip }}$ with no impact on the dominance of orbital precession in the spectral properties ${ }^{24}$ (Fig. S1). Our combined datasets provide a regional hydroclimate record that represents a total span of $\sim 750 \mathrm{kyr}$ during the period $1900 \mathrm{ka}$ to present, with an average sampling resolution of $\sim 3 \mathrm{kyr}$ within each record (Fig. 2).

The combined WTK13 and CHB14-2 data record key intervals when our genus, Homo, was evolving, developing new technologies, and dispersing within and out of Africa ${ }^{46}$. The Omo-Turkana Basin contains over 100 

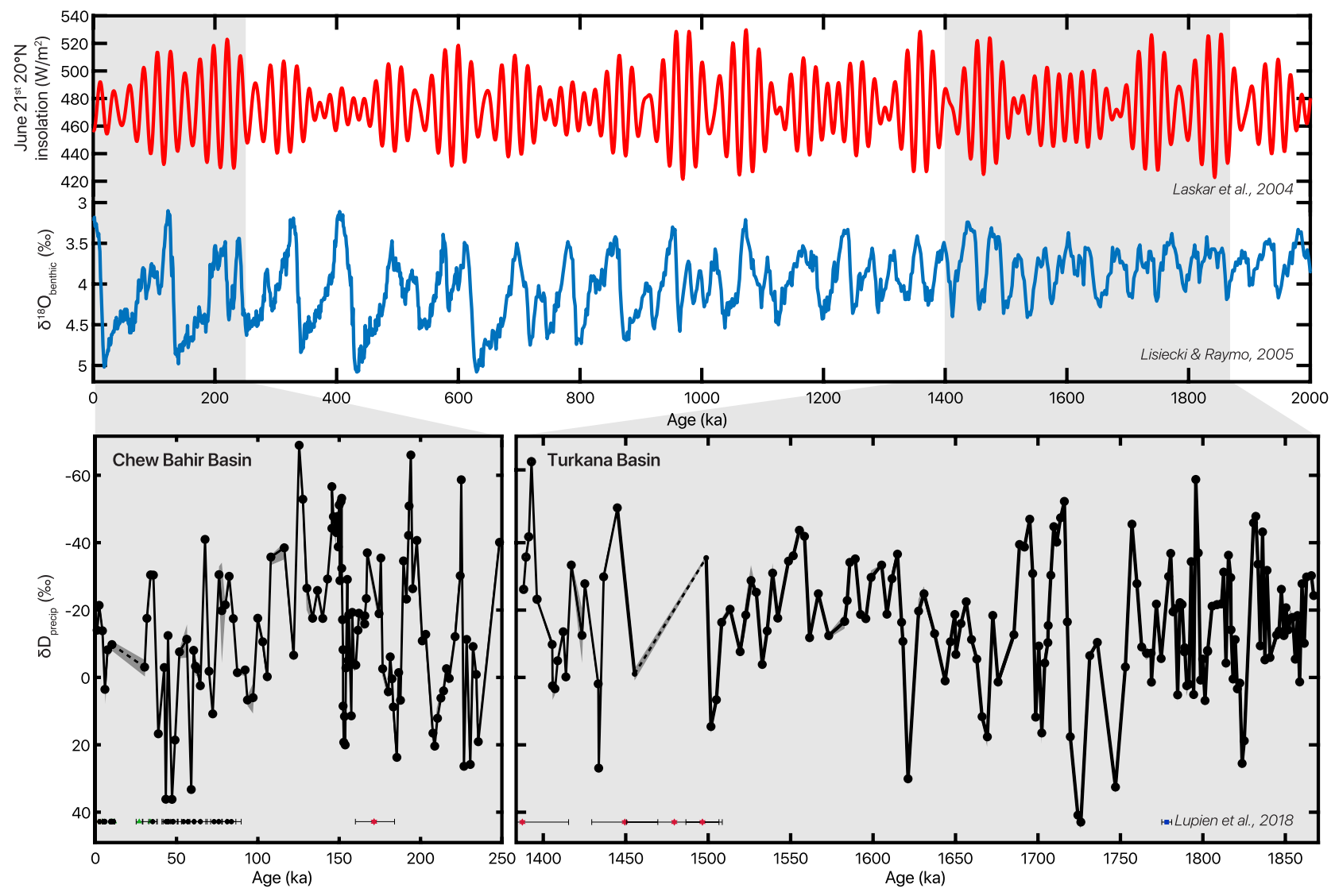

Figure 2. $\delta \mathrm{D}_{\text {precip }}$ records corrected for vegetation, ice volume, and geographic effects (Fig. S4) from CHB14-2 and WTK13 in the context of two million years of zonal mean $20^{\circ} \mathrm{N}$ June 21 st insolation ${ }^{65}$ (red) and the benthic foraminifera $\delta^{18} \mathrm{O} \operatorname{stack}^{32}$ (blue). Sampling gaps greater than half of a precession cycle $(\sim 10 \mathrm{kyr})$ are represented with dashed lines and analytical error on $\delta \mathrm{D}_{\text {wax }}$ measurements in shading. Age constraints for CHB14-2 and WTK $13^{24,45}$ with $1 \sigma$ analytical error depicted along bottom with symbol indicating dating technique (green triangle $={ }^{14} \mathrm{C}$; black circle $=\mathrm{OSL}$; red star $={ }^{40} \mathrm{Ar} /{ }^{39} \mathrm{Ar}$; blue square $=$ magnetostratigraphy) .

archaeological sites and 500 fossil finds ${ }^{47}$, including the earliest and most complete skeletons of $H$. rudolfensis and $H$. erectus. The $\sim 1900-1400 \mathrm{ka}$ interval spanned by WTK13 witnessed the development of Acheulean stone tools (earliest evidence for advanced hand axes at $\sim 1760 \mathrm{ka}$ at Kokiselei ${ }^{48}$, Fig. 1b), the evolution of $H$. erectus (including the Nariokotome Boy skeleton at $\sim 1600 \mathrm{ka}^{49}$, Fig. 1b), and what is thought to be the earliest hominin dispersal out of Africa ${ }^{50}$. The first eastern African evidence of our species, H. sapiens, is dated to $\sim 233 \mathrm{ka}$ at Omo Kibish in the Omo-Turkana Basin ${ }^{51}, 100 \mathrm{~km}$ northwest of Chew Bahir (Fig. 1b). The past $250 \mathrm{kyr}$, recorded in CHB14-2, not only encapsulates human morphological changes, but also social, technological, linguistic, and cultural development, and the dispersal of modern $H$. sapiens out of Africa ${ }^{42,43,52}$. These new traits spread to the rest of the world during this interval, and thus, this Turkana-Chew Bahir region may have served as a critical landscape for the development of our ancestors over the Pleistocene. This study, situated within the broader context of the aims of HSPDP (Fig. 1a), provides crucial insight into the nature of environmental change and the potential effects on hominins and other large mammals on the landscape.

Many paleoenvironmental indicators are very sensitive to basin-scale geological processes, limiting the ability for inter-basin comparison. However, $\delta \mathrm{D}_{\text {wax }}$ is primarily controlled by $\delta \mathrm{D}_{\text {precip }}{ }^{53}$, which, in tropical Africa, is dominantly driven by regional atmospheric dynamics that govern rainfall amount ${ }^{54,55}$. A variety of observational ${ }^{55,56}$, modeling ${ }^{57}$, and paleoclimate ${ }^{14,24,58-60}$ studies have revealed $\delta \mathrm{D}_{\text {precip }}$ to be very sensitive to changes in eastern African paleohydrology on orbital timescales. Although we recognize that $\delta \mathrm{D}_{\text {precip }}$ can be influenced by a variety of other processes such as moisture source and transport, and a variety of convective processes including the location of convective cells ${ }^{61}$, we interpret $\delta \mathrm{D}_{\text {precip }}$ as a qualitative indicator of rainfall amount, consistent with previous studies in the region ${ }^{14,24,54,59,61,62}$. We directly compare $\delta \mathrm{D}_{\text {precip }}$ between different sedimentary archive sites and time intervals to understand large-scale climate processes.

$\mathrm{C}_{3}$ and $\mathrm{C}_{4}$ metabolic processes influence the apparent fractionation between $\delta \mathrm{D}_{\text {wax }}$ and $\delta \mathrm{D}_{\text {precip }}$, but carbon isotopic compositions of the same leaf wax compounds $\left(\delta^{13} \mathrm{C}_{\text {wax }}\right.$; Fig. S2) help estimate vegetation type and correct $\delta D_{\text {wax }}$ to $\delta D_{\text {precip }}$ (Fig. S3 and S4). While uncertainties exist in the biosynthetic fractionation factor, this correction has minimal influence on the trends and patterns in the precipitation record because the isotopic range in $\delta D_{\text {precip }}$ is vastly larger than the potential $C_{3}-C_{4}$ effect. We also correct for geographic differences in $\delta D_{\text {precip }}$ between WTK13 and CHB14-2 using $\delta D_{\text {wax }}$ and $\delta^{13} \mathrm{C}_{\text {wax }}$ measurements from late Holocene sediment within each 


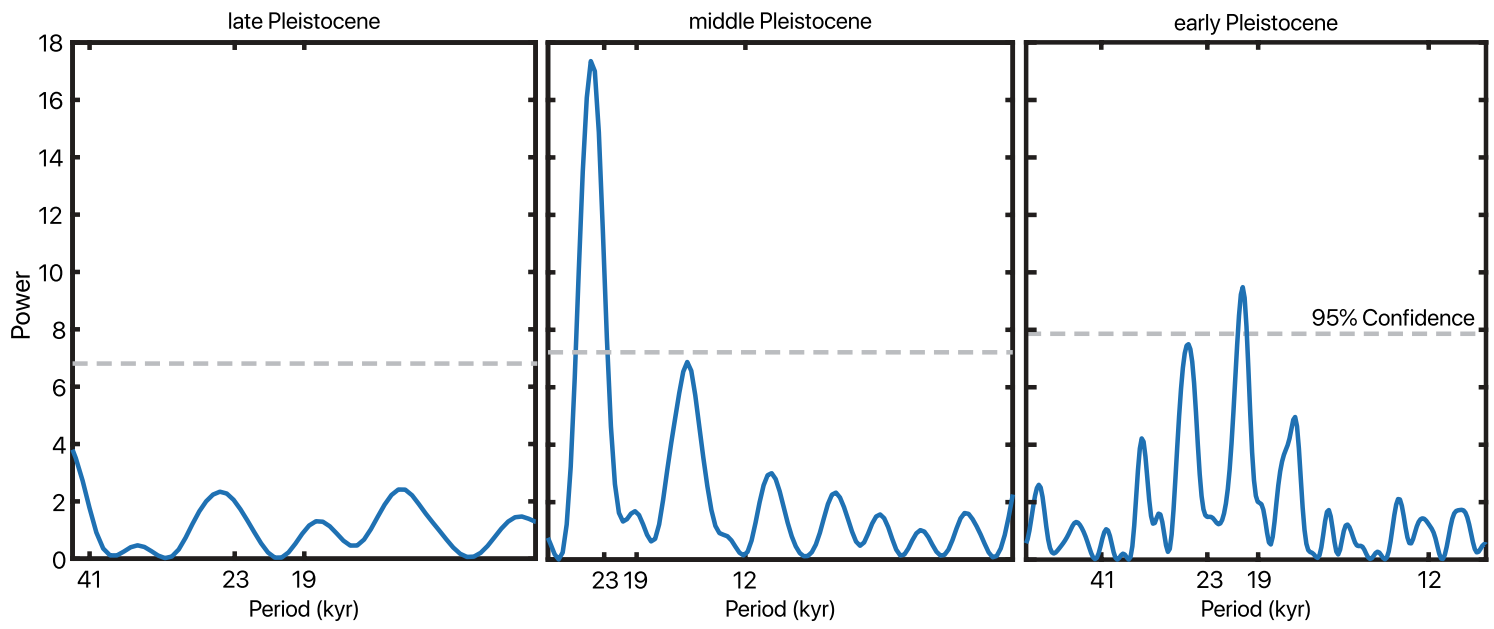

Figure 3. Lomb-Scargle spectral analyses for unevenly sampled data of $\delta D_{\text {precip }}$ from the early (1900-1500 ka), middle (250-130 ka), and late (130-0 ka) Pleistocene. Precession-band 19- and 23-kyr periodicities lie above the $95 \%$ confidence line (dashed grey) in the early and middle Pleistocene. Frequency distribution is plotted from $1 / 2 \times$ the Nyquist frequency as the high-frequency cutoff to $1 / 3$ of the total length of interval as the low-frequency cutoff, thus the differing $\mathrm{x}$-axes of the three windows depend on the resolution and length of the specific interval.

basin to estimate regional $\delta D_{\text {precip }}$ (Fig. S4). We conduct a series of time series analyses to detect changes in the trends and rhythms of $\delta \mathrm{D}_{\text {precip }}$ and eastern African climate variability.

\section{Results}

Leaf wax biomarker record. The hydrogen isotopic composition of long-chain leaf waxes $\left(n-\mathrm{C}_{26}, n-\mathrm{C}_{28}\right.$, and $n-\mathrm{C}_{30}$ alkanoic acids) are strongly correlated in CHB14-2 $\left(\mathrm{C}_{28}-\mathrm{C}_{26}: \mathrm{r}^{2}=0.72, \mathrm{n}=100, p<<0.01 ; \mathrm{C}_{28}-\mathrm{C}_{30}\right.$ : $\left.\mathrm{r}^{2}=0.9, \mathrm{n}=117, p<<0.01\right)$ demonstrating these compounds were derived from a common source and record similar climate processes. Despite previous work that found that $n-\mathrm{C}_{28}$ may be produced in the lake water column in some lakes ${ }^{63}$, the strong correlation between long-chain compounds indicates that $n$ - $C_{28}$ is representative of terrestrial land plants in this basin. As $n-\mathrm{C}_{28}$ is the most abundant long chain $n$-acid, determined by Average Chain Length (ACL) calculation (28.4), resulting in lower analytical error, we use the hydrogen isotopic ratio of $\mathrm{C}_{28} n$-acid for all analyses of climate variability for both sites. The Carbon Preference Index (CPI) is a measurement of degradation of the organic compounds in the sediment, where a high even:odd chain length signifies good preservation of alkanoic acids, and a ratio of 1 signifies full degradation ${ }^{64}$. The CPI in CHB14-2 is acceptable (mean: 2.8; minimum: 1.5), and to further demonstrate the lack of degradation effect on isotope analyses, we compare CPI and $\delta \mathrm{D}_{\text {wax }}$ to find an insignificant correlation $\left(\mathrm{r}^{2}=0.002, \mathrm{n}=125, p>0.05\right)$. In $\mathrm{CHB} 14-2, \delta \mathrm{D}_{\text {wax }}$ ranges from -164.6 to $-68.7 \%$.

$\delta^{13} \mathrm{C}_{\text {wax }}$ averages $-23.8 \%$ in CHB14-2, and ranges from -19.9 to $-30.8 \%$ with one outlier at $-16.8 \%$ (Fig. S2). The corrected $\delta \mathrm{D}_{\text {precip }}$ record, based on the $\delta^{13} \mathrm{C}_{\text {wax }}$ data, ranges from -68.9 to $36.2 \%$ and closely tracks $\delta \mathrm{D}_{\text {wax }}$ (Fig. S3 and S4).

Trend, variability, and spectral properties. Neither of the $\delta \mathrm{D}_{\text {precip }}$ records show significant linear trends towards wetter or drier conditions within the time intervals they span individually or together, nor is there a large difference between the WTK13 and CHB14-2 study intervals ( $<2 \%$ offset in $\delta \mathrm{D}_{\text {precip. }}$. Fig. 2$)$.

Our $\delta \mathrm{D}_{\text {precip }}$ records contain high-amplitude oscillations of up to $\sim 100 \%$. Lomb-Scargle periodogram analysis demonstrates spectral density at $21 \mathrm{kyr}$ in the early and middle Pleistocene intervals (1900-1500 ka and $250-130 \mathrm{ka}$ ) but no significant spectral properties in the late Pleistocene within the bounds of robust frequency detection (Fig. 3). Gaussian 21-kyr band-pass filtering of $\delta D_{\text {precip }}$ in the two study intervals supports the spectral analysis findings of strong precession influence in the early and middle Pleistocene, and reveals that this precession-band variation is greatly diminished in the late Pleistocene (Fig. 4). After applying a notch filter to remove variability associated with the $\sim 21 \mathrm{kyr}$ band, we observe gradual D-enrichment from Marine Isotope Stage (MIS) $5(\sim 125 \mathrm{ka})$ until the beginning of MIS $2(\sim 30 \mathrm{ka})$. This trend coincides with increasing benthic foraminiferal $\delta^{18} \mathrm{O}$, suggesting that shifts in the late Pleistocene $\delta \mathrm{D}_{\text {precip }}$ covary with glacial-interglacial cycles (Fig. $\left.4 \mathrm{c}, \mathrm{d}\right)$.

\section{Discussion}

Our $\delta D_{\text {precip }}$ records indicate eastern African rainfall experienced high-amplitude, orbitally-driven wet/dry cycles during long intervals of the early, middle, and late Pleistocene. Variability in the early Pleistocene 1900-1400 ka and middle Pleistocene $(230-150 \mathrm{ka})$ intervals is dominated by orbital precession, with strong 21 -kyr cycles in $\delta \mathrm{D}_{\text {precip }}$ (Figs. 3,4), as well as 100 -kyr eccentricity-band amplitude modulation (Fig. S5). Ice volume and associated global climate processes varied primarily at the 41-kyr period during the early Pleistocene and had a saw-tooth pattern and 100-kyr periodicity in the middle Pleistocene ${ }^{32}$, yet we see no robust signal of obliquity in the early Pleistocene (Fig. 3) nor visual similarity between $\delta \mathrm{D}_{\text {precip }}$ and ice volume through most of the record 

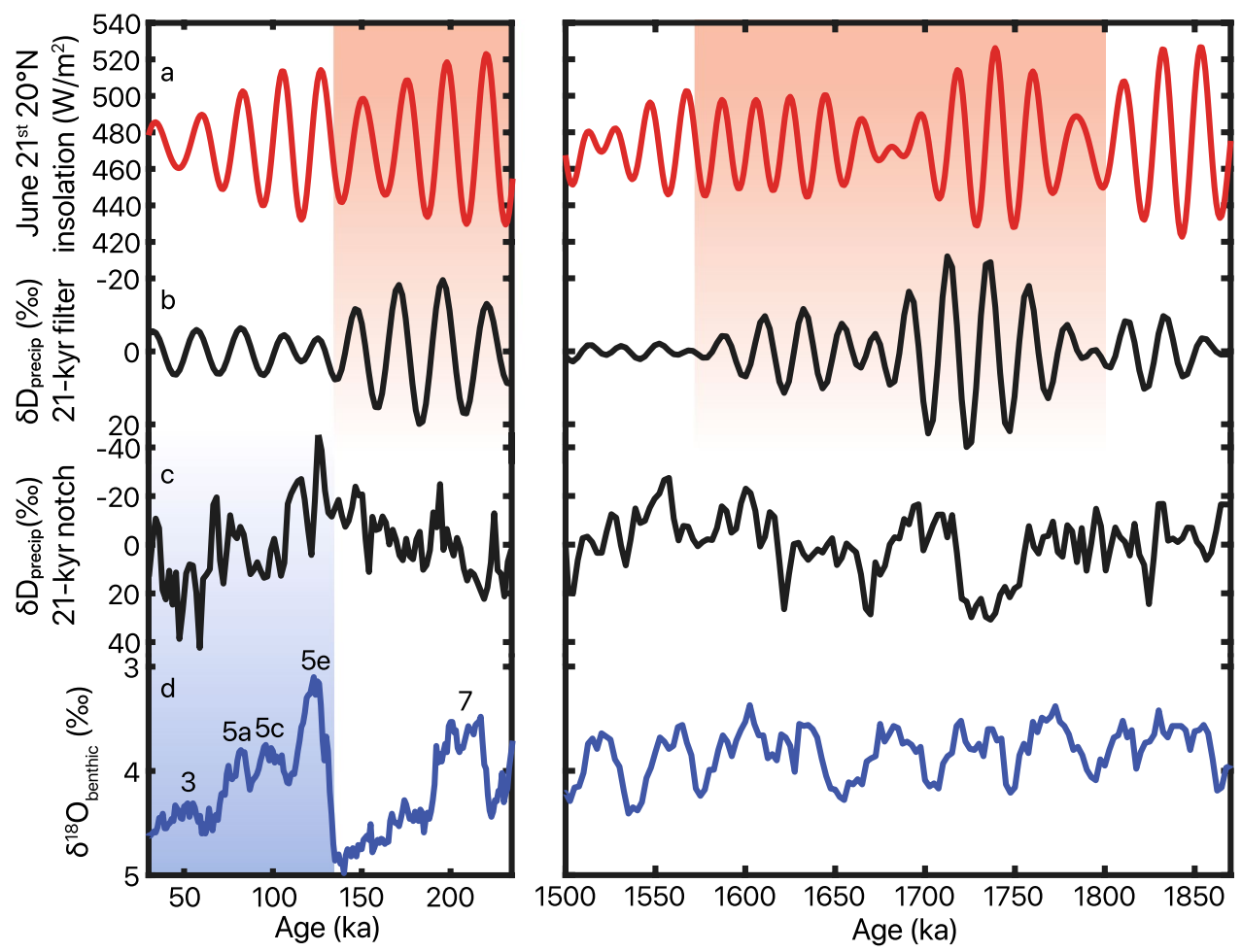

Figure 4. Gaussian $21-\mathrm{kyr} \pm 5-\mathrm{kyr}$ band-pass (b) and notch (c) filtering of the $\delta \mathrm{D}_{\text {precip }}$ study intervals truncated to $1870-1500 \mathrm{ka}$ and $250-30 \mathrm{ka}$ to omit low sampling resolution sections. June 21 st zonal mean $20^{\circ} \mathrm{N}$ insolation ${ }^{65}$ (a) plotted and highlighted in light red demonstrate similarity with high- and low-amplitude variability packets in gaussian band-pass filtered $\delta \mathrm{D}_{\text {precip. }}$. Our selection of June 21 st insolation at $20^{\circ} \mathrm{N}$ is based on observations from latest Pleistocene and Holocene records demonstrating the sensitivity of eastern African precipitation to this date and latitude ${ }^{14,61,84,88}$. We note that the chronologies for the CHB14-2 and WTK13 records are too imprecise to determine the phase of the response of $\delta \mathrm{D}_{\text {precip }}$ to orbital forcing; however, the choice of latitude and season does not influence our spectral analyses nor other results. Benthic foraminifera $\delta^{18} \mathrm{O}$ stack $^{32}$ (d) plotted with recent interglacial MIS's and highlighted in light blue to demonstrate similarily with late Pleistocene notch-filtered (precession-band periodicities removed) $\delta \mathrm{D}_{\text {precip. }}$. Means were removed in both band-pass- and notch-filtered data to feature changes in variability.

(Fig. 2). Instead, eastern African rainfall varied primarily at a 21-kyr precession rhythm (Fig. 3) with modulation of that variability by eccentricity into high- and low-amplitude packets (Fig. S5), in sync with low-latitude summer insolation forcing ${ }^{65}$ during the early to middle Pleistocene.

We observe no difference in mean values of $\delta \mathrm{D}_{\text {precip }}$ between the WTK13 and CHB14-2 records, suggesting remarkable long-term stability in eastern African rainfall during the Pleistocene. The similar lack of trend in the eastern Africa soil carbonate $\delta^{18} \mathrm{O}$ compilation ${ }^{31}$ suggests that the Omo-Turkana and Chew Bahir Basins, despite their aridity relative to surrounding basins, capture regional paleoclimate changes, especially because of the large-scale integrative nature of the leaf wax biomarker proxy. The long-term hydroclimate stability occurs despite evidence for regional $\mathrm{C}_{4}$ grassland expansion ${ }^{66-72}$, supporting recent work suggesting that declining atmospheric $\mathrm{CO}_{2}$, rather than hydroclimate, plays a dominant role in $\mathrm{C}_{4}$ grass expansion in $\mathrm{Africa}^{73,74}$.

Orbital-scale vegetation change, though, covaries with hydroclimate variations in intervals throughout the Quaternary $24,59,75$, and we observe substantial changes in the amplitude of orbital-scale variability within each of our records. Band-pass filtering of the precession signal in our $\delta \mathrm{D}_{\text {precip }}$ records isolates packets of high-amplitude variability that generally align with high orbital eccentricity and intervals with the strongest seasonal insolation forcing (Fig. 4 and S5). Although not every high eccentricity interval produces high-amplitude $\delta D_{\text {precip }}$ oscillation (i.e., 1900-1800 ka), this result further suggests a dominant role for precession-driven seasonal insolation change in controlling eastern African rainfall during the early and middle Pleistocene.

Our findings are supported by records that indicate a dominant role for orbital precession in controlling African climate history, particularly in subtropical and northern Africa ${ }^{9,20,22-26,76}$. For instance, sapropel records from the Mediterranean indicate precessional insolation forcing has been a dominant driver of northeast African rainfall throughout the Plio-Pleistocene ${ }^{9}$. Our results are also consistent with some paleoclimate model simulations ${ }^{17}$, though others predict a stronger role for atmospheric greenhouse gases in eastern equatorial Africa $^{76}$ than suggested by our records. Synchronized pulses of deep lakes in multiple East African Rift basins have been suggested to occur during intervals of high eccentricity ${ }^{5}$. Our $\delta \mathrm{D}_{\text {precip }}$ records indicate that high eccentricity intervals were times of much wetter, as well as much drier, conditions (Fig. S5), and the alternation 
between extreme endmembers suggested by our data could drive selection for generalist or adaptable traits in early humans ${ }^{27,77,78}$.

Despite the dominant role of orbital precession in our records, our $\delta \mathrm{D}_{\text {precip }}$ suggests global climate conditions became increasingly influential on tropical African rainfall between the middle and late Pleistocene after the last interglacial at $\sim 130 \mathrm{ka}$. After removing precessional periodicity from our data, we observe a trend toward drier conditions from MIS 5e (when ice volume levels were similar to the Pliocene ${ }^{32}$ ) until the Last Glacial Maximum (LGM; Fig. 4). Previous work has documented strong influences of ice volume on eastern African climate during the latest Pleistocene, such as drying over most of the region during the $\mathrm{LGM}^{43,79}$. A $\sim 210 \mathrm{kyr}$-long $\delta \mathrm{D}_{\text {wax }}$ record from the Gulf of Aden also documents strong precession-band rainfall variations during MIS 5, 6, and 7 superimposed on alternating humid and arid conditions that track ice volume ${ }^{14}$. This mixture of signals of insolation and ice volume in the Gulf of Aden potentially results from its more northern location or the larger area of leaf wax supply to this marine record. However, a dust record from the Mediterranean, which is thought to record Northeast African monsoon strength, also demonstrates precession-band fluctuations throughout the last $3000 \mathrm{kyr}$ until a large, 100-kyr, sawtooth-shaped excursion begins in MIS 5e $\mathrm{e}^{12,76}$.

Climate model simulations suggest strong atmospheric teleconnections between eastern African rainfall and the northern high latitudes ${ }^{80}$. One potential mechanism for the influence of late Pleistocene glacial-interglacial cycling in tropical Africa could be that cooling in the northern high latitudes is advected by the westerlies into Eurasia, which enhances the boreal winter Arabian anticyclone ${ }^{80}$. Northerly winds originating from this circulation advect cool and dry air over eastern Africa, suppressing boreal fall and winter rainfall. These simulations rely on freshwater hosing to cool the northern high latitudes and are therefore not directly analogous to the Northern Hemisphere glaciation cycles. However, these simulations demonstrate an atmospheric mechanism linking eastern African rainfall and northern high latitude climate via Eurasia that could apply on longer timescales.

Our $\delta \mathrm{D}_{\text {precip }}$ data suggest that low-latitude insolation forcing controls much of the long-term variability in eastern African rainfall, including during the middle Pleistocene when ice volume changes were large. However, ice volume fluctuations leave distinct signals from $130 \mathrm{ka}$ to the present (Fig. 4) and there is also a stark lack of similarity between $\delta \mathrm{D}_{\text {precip }}$ and precession (Fig. 3) and eccentricity modulation (Fig. S5) during this time. We suggest that this arises due in part to the relative strengths of high- and low-latitude forcings. High-amplitude seasonal insolation forcing under high orbital eccentricity causes strong, periodic changes in eastern African rainfall ${ }^{17}$. However, when ice volume fluctuations strengthen and insolation forcing weakens, such as occurred from $\sim 130 \mathrm{ka}$ to the present, ice volume changes can emerge as a strong influence on eastern African hydroclimate. The shift from insolation-driven to ice volume-driven fluctuation at $\sim 130 \mathrm{ka}$ in our record suggests a nonlinear sensitivity of eastern African rainfall to seasonal insolation forcing and to high-latitude-driven climate change at this orbital time scale. This varying sensitivity to forcings of variable amplitude may reconcile the large number of records that document eastern African aridity during the $\mathrm{LGM}^{43,58,79,81-86}$, when ice volume changes were large and eccentricity was particularly low, against the longer Pleistocene records that show a dominant control of orbital precession on eastern African rainfall. This hypothesis may further explain the absence of 41-kyr cycles in African rainfall during the early Pleistocene, as ice volume changes were generally small compared to those during the late Pleistocene. Climate modeling experiments have suggested threshold responses of tropical climate to Northern Hemisphere ice volume changes, due to shifts in the position of westerly jets and their ability to perturb the tropical atmospheric circulation ${ }^{87}$. Additionally, threshold-like responses of African hydroclimate to insolation have been documented ${ }^{61,87}$ and attributed to various processes, including feedbacks involving vegetation, soil moisture, and SST ${ }^{43,58,88}$. The interaction of these nonlinear responses to high- and lowlatitude climate drivers may have triggered shifts in sensitivity, depending on the relative strengths of each forcing.

Both orbital-scale variability and secular trends in eastern African climate have been postulated as drivers of hominin evolution and dispersal ${ }^{3,7,42,43,77,89}$. Our proxy records indicate that orbital-scale variability (up to $100 \%$ in a single precession cycle) is much larger than the long-term mean change occurring since 2000 ka. Extremely high-amplitude fluctuations occurred in the region during critical times of early hominin evolution in eastern Africa and potentially promoted an environment that favored behavioral and morphological plasticity or adaptability in our ancestors ${ }^{8,27}$.

\section{Methods}

Geochemical analyses. We analyzed the isotopic composition of terrestrial leaf wax biomarkers preserved in sediment from composite core HSPDP-CHB14-2 (hereafter termed CHB14-2 ${ }^{42}$ ) archived at the National Lacustrine Core Repository. Plants produce epicuticular waxes to shield leaf surfaces from evaporation and physical damage ${ }^{90}$. These waxes may be ablated and transported by eolian and fluvial processes to lakes, where they are preserved in sediment over geological time. The waxes include long-chain $n$-alkanoic acids, which we use to reconstruct water isotope compositions. Lipid extraction, purification, and isotopic analytical procedures ${ }^{91}$ were performed at Brown University. Lipids were extracted from freeze-dried and homogenized sediment using a DIONEX Accelerated Solvent Extractor 350 with dichloromethane:methanol (9:1). The total lipid extract was separated into neutral and acid fractions via aminopropylsilyl gel column with dichloromethane:isopropanol (2:1) and ether:acetic acid (24:1). The acid fraction was then methylated using acidified methanol, and the resulting fatty acid methyl esters (FAMEs) were purified using a silica gel column. Relative concentrations of the FAME chain lengths were quantified using an Agilent 6890 gas chromatograph (GC) equipped with a HP1-MS column $(30 \mathrm{~m} \times 0.25 \mathrm{~mm} \times 0.25 \mu \mathrm{m})$ and flame ionization detector (FID).

Hydrogen isotopes $\left(\delta \mathrm{D}_{\text {wax }}\right)$ were measured using an Agilent $6890 \mathrm{GC}$, equipped with HP1-MS column $(30 \mathrm{~m} \times 0.32 \mathrm{~mm} \times 0.25 \mu \mathrm{m})$, coupled to a Thermo Delta Plus XL isotope ratio mass spectrometer (IRMS) with a reactor temperature of $1445^{\circ} \mathrm{C}$, although some of the samples from the CHB14-2 core were analyzed with a Thermo Delta V Plus IRMS using the same conditions. On both instruments, $\mathrm{D} / \mathrm{H}$ ratios were measured in 
triplicate using $\mathrm{H}_{2}$ as an internal standard with $\mathrm{He}$ as the carrier gas, and corrected using a known FAMEs lab standard. Carbon isotopes $\left(\delta^{13} \mathrm{C}_{\mathrm{wax}}\right)$ from $\mathrm{CHB} 14-2$ and the late Holocene analogues were measured at Brown University with these same procedures on the Thermo Delta V Plus GC-IRMS with a reactor temperature of $1100{ }^{\circ} \mathrm{C}$. Isotope ratios were corrected for the added methyl group $\left(\delta \mathrm{D}_{\mathrm{MeOH}}=-123.7 \%\right.$ and $\delta^{13} \mathrm{C}_{\mathrm{MeOH}}=-36.62 \%$ ). We report $\delta \mathrm{D}_{\text {wax }}$ relative to Vienna Standard Mean Ocean Water (VSMOW) and $\delta^{13} \mathrm{C}_{\mathrm{wax}}$ relative to Pee Dee Belemnite (PDB) in per mil (\%o) notation.

We successfully analyzed 125 samples (out of 143 samples) for $\delta \mathrm{D}_{\text {wax }}$ and 92 samples for $\delta^{13} \mathrm{C}_{\mathrm{wax}}$ from the CHB14-2 composite core. The sediment samples integrate up to $4 \mathrm{~cm}\left(\sim 80\right.$ years $\left.{ }^{44}\right)$ and have a mean temporal resolution of $\sim 1.75 \mathrm{kyr}$ since $250 \mathrm{ka}$. Hydrogen isotopic analyses of the FAMEs standard had a standard deviation $(1 \sigma)$ of $3.2 \%$ and the $\mathrm{H}_{3}$ factor was $1.76 \mathrm{ppm} / \mathrm{nA}$. For hydrogen, 56 samples were run in triplicate (average $1 \sigma=1.5$ ), 20 in duplicate (average difference $=2.3 \%$ ), and 49 as single injections due to limited concentration. For carbon, all samples were measured in duplicate, with an average FAMEs standard $1 \sigma$ of 0.25 and average intra-sample difference of $0.14 \%$. Five samples were removed from further analysis because they lie between two ages that constrain a potential sedimentary hiatus or dramatic reduction in sediment accumulation rate around the LGM from $\sim 30-10.5 \mathrm{ka}^{42-44}$.

Isotopic corrections. A series of corrections to $\delta \mathrm{D}_{\text {wax }}$ were performed to convert values to $\delta \mathrm{D}_{\text {precip }}$ (Fig. S4). Once all corrections were made, one outlier (outside 3 standard deviation units) was removed from the WTK13 record.

Vegetation correction. $\quad \mathrm{C}_{3}$ trees and $\mathrm{C}_{4}$ grasses fractionate hydrogen to different degrees during leaf wax synthesis due to differing metabolic pathways and plant physiologies. This causes different apparent fractionations between leaf waxes and precipitation $\left(\varepsilon_{\text {wax }-\mathrm{P}}\right)$, which can affect paleoclimate records based on $\delta \mathrm{D}_{\text {wax }}$ if vegetation changes ${ }^{38}$. We calculated a 'vegetation correction' based upon $\delta^{13} \mathrm{C}_{\mathrm{wax}}$ values (Fig. S2) to correct $\delta \mathrm{D}_{\text {wax }}$ for these differences ${ }^{91}$. We use $\delta^{13} \mathrm{C}_{\text {wax }}$ endmember values for $\mathrm{C}_{3}$ and $\mathrm{C}_{4}$ plant types previously described from a OmoTurkana Basin outcrop ${ }^{92}$, in which the $\delta^{13} \mathrm{C}$ of $n-\mathrm{C}_{30}$ acids is $-32.9 \%$ o for the $\mathrm{C}_{3}$ endmember and the $\delta^{13} \mathrm{C}$ of $n-\mathrm{C}_{30}$ acid is $-19.0 \%$ or the $\mathrm{C}_{4}$ end member. We adjust these values to account for observed differences between $n$ - $C_{30}$ and $n-\mathrm{C}_{28}$ acids ${ }^{93}$, thereby using $-32.15 \%$ and $-20.63 \%$ as the $\mathrm{C}_{3}$ and $\mathrm{C}_{4}$ endmembers. Samples with $\delta^{13} \mathrm{C}_{\text {wax }}$ values more enriched than this $\mathrm{C}_{4}$ endmember value were treated as $100 \% \mathrm{C}_{4}$. After applying this $\mathrm{C}_{3} / \mathrm{C}_{4}$ mixing model to our $\delta^{13} \mathrm{C}_{\text {wax }}$ data, we then applied $\varepsilon_{\text {wax }-\mathrm{P}}$ values of $-112.8 \%$ and $-124.5 \%$ or $\mathrm{C}_{3}$ and $\mathrm{C}_{4}$ vegetation with a $25 \%$ correction for $\mathrm{C}_{27} n$-alkane to $\mathrm{C}_{28} n$-acid ${ }^{38,91,94}$ to correct for 'vegetation effects' on $\delta \mathrm{D}_{\text {wax }}$ and estimate $\delta \mathrm{D}_{\text {precip }}$ (Fig. S3).

Because not all $\delta \mathrm{D}_{\text {wax }}$ measurements have a corresponding $\delta^{13} \mathrm{C}_{\mathrm{wax}}$ measurement, typically due to concentration limitations, we used AnalySeries ${ }^{95}$ to mathematically resample the $\delta^{13} \mathrm{C}_{\text {wax }}$ data to $\delta \mathrm{D}_{\text {wax }}$ resolution to obtain a $\delta D_{\text {precip }}$ record with the same resolution as $\delta D_{\text {wax }}$. In Fig. $S 2$ we demonstrate that this does not have a meaningful impact on our results as the corrections are much smaller than the hydroclimate signals in $\delta \mathrm{D}_{\text {wax }}$ and $\delta \mathrm{D}_{\text {precip. }}$ We show the CHB14-2 $\delta D_{\text {precip }}$ record with and without the additional resampled $\delta^{13} C_{\text {wax }}$ corrections to demonstrate that the difference between the $\delta \mathrm{D}_{\text {wax }}$ and the empirically derived $\delta \mathrm{D}_{\text {precip }}$ is negligible.

Ice volume correction. We use the benthic $\delta^{18} \mathrm{O} \operatorname{stack}^{32}$ to estimate past ocean water isotopes to correct the $\delta \mathrm{D}_{\text {precip }}$ for different source water $\delta \mathrm{D}^{91}$. Age uncertainty in our records and in the LR04 stack limits our ability to precisely align the two, so we average the stack $\delta^{18} \mathrm{O}$ in each study interval, anomalize that value to late Holocene, and convert it to $\delta \mathrm{D}$ based on the meteoric water line. We then apply this anomaly to each study interval to obtain an ice volume-corrected signal of $\delta D_{\text {precip }}$ (Fig. S4).

Geographic correction. $\quad \delta \mathrm{D}_{\text {wax }}$ and $\delta^{13} \mathrm{C}_{\text {wax }}$ measurements of late Holocene analogue sediment (Table S1) lets us obtain $\delta \mathrm{D}_{\text {precip }}$ measurements from both sites. One sample from the Chew Bahir Basin ${ }^{96}$ and 12 averaged samples from the Omo-Turkana Basin ${ }^{85}$ were used to represent the late Holocene (last 5 kyr) leaf wax isotope signature of each region (Table S1). Our late Holocene analogue measurements of $\delta \mathrm{D}_{\text {precip }}$ are similar to modeled precipitation isotope data ${ }^{97}$, indicating that we have appropriately captured the differences between study sites. We anomalized the Chew Bahir measurements to Turkana $\delta \mathrm{D}_{\text {precip. }}$. This "geographic" correction $(12 \%$ ) was then added to the mean of the CHB14-2 record (Fig. S4) to produce the fully corrected eastern African $\delta D_{\text {precip }}$ Pleistocene record (Fig. 2).

Time series analyses. We analyzed the linear trends within the WTK13 and CHB14-2 records, as well as throughout the entire $1900 \mathrm{kyr}$ interval. Comparisons between $\delta$ Dprecip and insolation were performed using June 21 st insolation at $20^{\circ} \mathrm{N}$, which is based on observations from late Pleistocene and Holocene records demonstrating the sensitivity of eastern African precipitation to this date and latitude $14,60,83,87$. We also performed Lomb-Scargle analysis of $\delta \mathrm{D}_{\text {precip }}$ to study spectral density of unevenly spaced data with the plomb function in MATLAB ${ }^{98,99}$. This method was applied to the two study intervals, 1900-1500 ka and 250-30 ka, which exclude low-resolution intervals. We then used the frequency of the densest spectral peak from each interval (early Pleistocene, $22 \mathrm{kyr}$; middle to late Pleistocene, $25 \mathrm{kyr}$; each with bandwidth of $\pm 5 \mathrm{kyr}$ ) to inform gaussian band-pass and notch filtering exercises, which were performed using the time series analysis program AnalySeries version $2.0 .8^{95}$. 
Received: 21 July 2021; Accepted: 7 February 2022

Published online: 24 February 2022

\section{References}

1. Vrba, E. S. Environment and evolution: Alternative causes of the temporal distribution of evolutionary events. S. Afr. J. Sci. 81, 229-236 (1985).

2. Vrba, E. S. Turnover-pulses, the Red Queen, and related topics. Am. J. Sci. 293, 418-452 (1993).

3. deMenocal, P. B. Plio-Pleistocene African climate. Science 270, 53-59 (1995).

4. deMenocal, P. B. African climate change and faunal evolution during the Pliocene-Pleistocene. Earth Planet. Sci. Lett. 220, 3-24 (2004).

5. Trauth, M. H., Maslin, M. A., Deino, A. \& Strecker, M. R. Late Cenozoic moisture history of East Africa. Science 309, 2051-2053 (2005).

6. Trauth, M. H. et al. High-and low-latitude forcing of Plio-Pleistocene East African climate and human evolution. J. Hum. Evol. 53, 475-486 (2007).

7. Maslin, M. A. \& Trauth, M. H. Plio-Pleistocene East African pulsed climate variability and its influence on early human evolution. In Vertebrate Paleobiology and Paleoanthropology Series (eds Grine, F. E. et al.) 151 (Springer Netherlands, 2009).

8. Potts, R. Variability selection in hominid evolution. Evol. Anthropol. Issues News Rev. 7, 81-96 (1998).

9. Rossignol-Strick, M. African monsoons, an immediate climate response to orbital insolation. Nature 304, 46-49 (1983).

10. Clemens, S. C., Prell, W., Murray, D. W., Shimmield, G. \& Weedon, G. Forcing mechanisms of the Indian Ocean monsoon. Nature 353, 720-725 (1991).

11. Trauth, M. H., Deino, A. L., Bergner, A. G. N. \& Strecker, M. R. East African climate change and orbital forcing during the last 175 kyr BP. Earth Planet. Sci. Lett. 206, 297-313 (2003).

12. Trauth, M. H., Larrasoaña, J. C. \& Mudelsee, M. Trends, rhythms and events in Plio-Pleistocene African climate. Quat. Sci. Rev. 28, 399-411 (2009).

13. Johnson, T. C. et al. A progressively wetter climate in southern East Africa over the past 1.3 million years. Nature 537, 220-224 (2016).

14. Tierney, J. E., DeMenocal, P. B. \& Zander, P. D. A climatic context for the out-of-Africa migration. Geology 45, 1023-1026 (2017).

15. Ravelo, A. C., Andreasen, D. H., Lyle, M., Lyle, A. O. \& Wara, M. W. Regional climate shifts caused by gradual global cooling in the Pliocene epoch. Nature 429, 263-267 (2004).

16. Brierley, C. M. \& Fedorov, A. V. Relative importance of meridional and zonal sea surface temperature gradients for the onset of the ice ages and Pliocene-Pleistocene climate evolution. Paleoceanography 25, 2 (2010).

17. Kutzbach, J. E. et al. African climate response to orbital and glacial forcing in 140,000 -y simulation with implications for early modern human environments. Proc. Natl. Acad. Sci. 117, 2255-2264 (2020).

18. Kutzbach, J. E. Monsoon climate of the early Holocene: climate experiment with the earth's orbital parameters for 9000 years ago. Science 214, 59-61 (1981).

19. Kutzbach, J. E. \& Street-Perrott, F. A. Milankovitch forcing of fluctuations in the level of tropical lakes from 18 to 0 kyr BP. Nature 317, 130-134 (1985).

20. Rossignol-Strick, M. Mediterranean Quaternary sapropels, an immediate response of the African monsoon to variation of insolation. Palaeogeogr. Palaeoclimatol. Palaeoecol. 49, 237-263 (1985).

21. Kingston, J. D., Deino, A. L., Edgar, R. K. \& Hill, A. Astronomically forced climate change in the Kenyan Rift Valley 2.7-2.55 Ma: Implications for the evolution of early hominin ecosystems. J. Hum. Evol. 53, 487-503 (2007).

22. Joordens, J. C. A. et al. An astronomically-tuned climate framework for hominins in the Turkana Basin. Earth Planet. Sci. Lett. 307, 1-8 (2011).

23. Nutz, A., Schuster, M., Boës, X. \& Rubino, J.-L. Orbitally-driven evolution of Lake Turkana (Turkana Depression, Kenya, EARS) between 1.95 and 1.72 Ma: A sequence stratigraphy perspective. J. Afr. Earth Sci. 125, 230-243 (2017).

24. Lupien, R. L. et al. A leaf wax biomarker record of early Pleistocene hydroclimate from West Turkana, Kenya. Quat. Sci. Rev. 186, 225-235 (2018).

25. Magill, C. R., Ashley, G. M. \& Freeman, K. H. Water, plants, and early human habitats in eastern Africa. Proc. Natl. Acad. Sci. 110, 1175-1180 (2013).

26. Lourens, L. J., Antonarakou, A., Hilgen, F. J. \& Van Hoof, A. M. Evolution of Plio-Pleistocene astronomical time scale. Paleoceanography 11, 391-413 (1996).

27. Potts, R. \& Faith, J. T. Alternating high and low climate variability: The context of natural selection and speciation in Plio-Pleistocene hominin evolution. J. Hum. Evol. 87, 5-20 (2015).

28. Potts, R. Hominin evolution in settings of strong environmental variability. Quat. Sci. Rev. 73, 1-13 (2013).

29. Antón, S. C., Potts, R. \& Aiello, L. C. Evolution of early Homo: An integrated biological perspective. Science 345, 1236828 (2014).

30. Cerling, T. E., Wang, Y. \& Quade, J. Expansion of C4 ecosystems as an indicator of global ecological change in the late Miocene. Nature 361, 344-345 (1993).

31. Levin, N. E. Environment and climate of early human evolution. Annu. Rev. Earth Planet. Sci. 43, 405-429 (2015).

32. Lisiecki, L. E. \& Raymo, M. E. A Pliocene-Pleistocene stack of 57 globally distributed benthic $\delta^{18} \mathrm{O}$ records. Paleoceanography 20, $1(2005)$.

33. Skonieczny, C. et al. Monsoon-driven Saharan dust variability over the past 240,000 years. Sci. Adv. 5, eaav1887 (2019).

34. Wara, M. W., Ravelo, A. C. \& Delaney, M. L. Permanent El Niño-like conditions during the Pliocene warm period. Science 309, 758-761 (2005).

35. Cohen, A. S. et al. Understanding paleoclimate and human evolution through the Hominin Sites and Paleolakes Drilling Project. Sci. Drill. 8, 60-65 (2009).

36. Cohen, A. S. et al. The Hominin Sites and Paleolakes Drilling Project: Inferring the environmental context of human evolution from eastern African rift lake deposits. Sci. Drill. 21, 1 (2016).

37. Campisano, C. J. et al. The hominin sites and paleolakes drilling project: High-resolution paleoclimate records from the east African rift system and their implications for understanding the environmental context of hominin evolution. PaleoAnthropology 1, 43 (2017).

38. Sachse, D. et al. Molecular paleohydrology: Interpreting the hydrogen-isotopic composition of lipid biomarkers from photosynthesizing organisms. Annu. Rev. Earth Planet. Sci. 40, 221-249 (2012).

39. Brown, F. H., McDougall, I. \& Fleagle, J. G. Correlation of the KHS Tuff of the Kibish Formation to volcanic ash layers at other sites, and the age of early Homo sapiens (Omo I and Omo II). J. Hum. Evol. 63, 577-585 (2012).

40. McDougall, I., Brown, F. H. \& Fleagle, J. G. Stratigraphic placement and age of modern humans from Kibish, Ethiopia. Nature 433, 733-736 (2005).

41. Leakey, R. E. Early Homo sapiens remains from the Omo River region of South-west Ethiopia: Faunal remains from the Omo valley. Nature 222, 1132-1133 (1969).

42. Foerster, V. et al. 620,000 years of eastern African climate change and its nexus with hominin evolution, innovation and dispersal. Nat. Geosci. (in review). 
43. Schäbitz, F. et al. Hydroclimate changes in eastern Africa over the past 200,000 years may have influenced early human dispersal. Nat. Commun. Earth Environ. 2, 1-10 (2021).

44. Roberts, H. M. et al. Using multiple chronometers to establish a long, directly-dated lacustrine record: Constraining $>600,000$ years of environmental change at Chew Bahir, Ethiopia. Quat. Sci. Rev. 266, 107025 (2021).

45. Sier, M. J. et al. The top of the Olduvai subchron in a high-resolution magnetostratigraphy from the West Turkana core WTK13, Hominin Sites and Paleolakes Drilling Project (HSPDP). Quat. Geochronol. 42, 117-129 (2017).

46. Foley, R. A., Martin, L., Lahr, M. M. \& Stringer, C. Major transitions in human evolution. Philos. Trans. R. Soc. B Biol. Sci. 371, 20150229 (2016)

47. Wood, B. A. \& Leakey, M. The Omo-Turkana Basin fossil hominins and their contribution to our understanding of human evolution in Africa. Evol. Anthropol. Issues News Rev. 20, 264-292 (2011).

48. Lepre, C. J. et al. An earlier origin for the Acheulian. Nature 477, 82-85 (2011).

49. Brown, F., Harris, J., Leakey, R. \& Walker, A. Early Homo erectus skeleton from west lake Turkana, Kenya. Nature 316, 788-792 (1985).

50. Ferring, R. et al. Earliest human occupations at Dmanisi (Georgian Caucasus) dated to 1.85-1.78 Ma. Proc. Natl. Acad. Sci. 108, 10432-10436 (2011).

51. Vidal, C. M. et al. Age of the oldest known Homo sapiens from eastern Africa. Nature https://doi.org/10.1038/s41586-021-04275-8 (2022).

52. Brandt, S. A. et al. Early MIS 3 occupation of Mochena Borago Rockshelter, Southwest Ethiopian Highlands: Implications for Late Pleistocene archaeology, paleoenvironments and modern human dispersals. Quat. Int. 274, 38-54 (2012).

53. Garcin, Y. et al. Hydrogen isotope ratios of lacustrine sedimentary $n$-alkanes as proxies of tropical African hydrology: Insights from a calibration transect across Cameroon. Geochim. Cosmochim. Acta 79, 106-126 (2012).

54. Dansgaard, W. Stable isotopes in precipitation. Tellus 16, 436-468 (1964).

55. Rozanski, K., Araguás-Araguás, L. \& Gonfiantini, R. Isotopic patterns in modern global precipitation. Climate change in continental isotopic records. Geophys. Monogr. Am. Geophys. Union 78, 1 (1993).

56. Vuille, M., Werner, M., Bradley, R. S., Chan, R. Y. \& Keimig, F. Stable isotopes in East African precipitation record Indian Ocean zonal mode. Geophys. Res. Lett. 32, L21705 (2005).

57. Risi, C., Bony, S. \& Vimeux, F. Influence of convective processes on the isotopic composition $(\delta 18 \mathrm{O}$ and $\delta \mathrm{D})$ of precipitation and water vapor in the tropics: 2. Physical interpretation of the amount effect. J. Geophys. Res. Atmos. 113, 1-12 (2008).

58. Tierney, J. E. \& deMenocal, P. B. Abrupt shifts in Horn of Africa hydroclimate since the Last Glacial Maximum. Science 342, 843-846 (2013).

59. Rose, C., Polissar, P. J., Tierney, J. E., Filley, T. \& deMenocal, P. B. Changes in northeast African hydrology and vegetation associated with Pliocene-Pleistocene sapropel cycles. Philos. Trans. R. Soc. Lond. B Biol. Sci. 371, 20150243 (2016).

60. Tierney, J. E., Russell, J. M., Damsté, J. S. S., Huang, Y. \& Verschuren, D. Late Quaternary behavior of the East African monsoon and the importance of the Congo Air Boundary. Quat. Sci. Rev. 30, 798-807 (2011).

61. Costa, K., Russell, J. M., Konecky, B. L. \& Lamb, H. F. Isotopic reconstruction of the African humid period and Congo air boundary migration at Lake Tana, Ethiopia. Quat. Sci. Rev. 83, 58-67 (2014).

62. Lupien, R. L., Russell, J. M., Beck, C. C., Feibel, C. S. \& Cohen, A. S. Abrupt climate change and its influences on hominin evolution during the early Pleistocene in the Turkana Basin, Kenya. Quat. Sci. Rev. 245, 106531 (2020).

63. van Bree, L. G. J. et al. Seasonal variability in the abundance and stable carbon-isotopic composition of lipid biomarkers in suspended particulate matter from a stratified equatorial lake (Lake Chala, Kenya/Tanzania): Implications for the sedimentary record. Quat. Sci. Rev. 192, 208-224 (2018).

64. Bray, E. E. \& Evans, E. D. Distribution of $n$-paraffins as a clue to recognition of source beds. Geochim. Cosmochim. Acta 22, 2-15 (1961).

65. Laskar, J. et al. A long-term numerical solution for the insolation quantities of the Earth. Astron. Astrophys. 428, 261-285 (2004).

66. Cerling, T. E. \& Hay, R. L. An isotopic study of paleosol carbonates from Olduvai Gorge. Quat. Res. 25, 63-78 (1986).

67. Cerling, T. E. Development of grasslands and savannas in East Africa during the Neogene. Palaeogeogr. Palaeoclimatol. Palaeoecol. 97, 241-247 (1992).

68. Bobe, R., Behrensmeyer, A. K. \& Chapman, R. E. Faunal change, environmental variability and late Pliocene hominin evolution. J. Hum. Evol. 42, 475-497 (2002).

69. Bobe, R. \& Behrensmeyer, A. K. The expansion of grassland ecosystems in Africa in relation to mammalian evolution and the origin of the genus Homo. Palaeogeogr. Palaeoclimatol. Palaeoecol. 207, 399-420 (2004).

70. Bonnefille, R. Cenozoic vegetation, climate changes and hominid evolution in tropical Africa. Global Planet. Change 72, 390-411 (2010)

71. Levin, N. E., Brown, F. H., Behrensmeyer, A. K., Bobe, R. \& Cerling, T. E. Paleosol carbonates from the Omo Group: Isotopic records of local and regional environmental change in East Africa. Palaeogeogr. Palaeoclimatol. Palaeoecol. 307, 75-89 (2011).

72. Uno, K. T. et al. Late Miocene to Pliocene carbon isotope record of differential diet change among East African herbivores. Proc. Natl. Acad. Sci. 108, 6509-6514 (2011).

73. Polissar, P. J., Rose, C., Uno, K. T., Phelps, S. R. \& deMenocal, P. B. Synchronous rise of African C4 ecosystems 10 million years ago in the absence of aridification. Nat. Geosci. 12, 657-660 (2019).

74. Dupont, L. M., Caley, T. \& Castañeda, I. S. Effects of atmospheric CO2 variability of the past $800 \mathrm{kyr}$ on the biomes of southeast Africa. Clim. Past 15, 1083-1097 (2019).

75. Yost, C. L. et al. Phytoliths, pollen, and microcharcoal from the Baringo Basin, Kenya reveal savanna dynamics during the PlioPleistocene transition. Palaeogeogr. Palaeoclimatol. Palaeoecol. 570, 109779. https://doi.org/10.1016/j.palaeo.2020.109779 (2020).

76. Larrasoaña, J. C., Roberts, A. P., Rohling, E. J., Winklhofer, M. \& Wehausen, R. Three million years of monsoon variability over the northern Sahara. Clim. Dyn. 21, 689-698 (2003).

77. Potts, R. Evolution and climate variability. Science 273, 992 (1996).

78. Grove, M. Change and variability in Plio-Pleistocene climates: Modelling the hominin response. J. Archaeol. Sci. 38, 3038-3047 (2011).

79. Gasse, F. Hydrological changes in the African tropics since the Last Glacial Maximum. Quat. Sci. Rev. 19, 189-211 (2000).

80. Otto-Bliesner, B. L. et al. Coherent changes of southeastern equatorial and northern African rainfall during the last deglaciation. Science 346, 1223-1227 (2014)

81. Castañeda, I. S., Werne, J. P. \& Johnson, T. C. Wet and arid phases in the southeast African tropics since the Last Glacial Maximum. Geology 35, 823-826 (2007).

82. Tierney, J. E. et al. Northern hemisphere controls on tropical southeast African climate during the past 60,000 years. Science 322, 252-255 (2008)

83. Verschuren, D. et al. Half-precessional dynamics of monsoon rainfall near the East African Equator. Nature 462, 637-641 (2009).

84. Tierney, J. E., Russell, J. M. \& Huang, Y. A molecular perspective on Late Quaternary climate and vegetation change in the Lake Tanganyika basin, East Africa. Quat. Sci. Rev. 29, 787-800 (2010).

85. Morrissey, A. Stratigraphic framework and Quaternary paleolimnology of the Lake Turkana Rift, Kenya. PhD Thesis vol. PhD (Syracuse University, Syracuse, NY, Paper 62, 2014). 
86. Ivory, S. J. \& Russell, J. Climate, herbivory, and fire controls on tropical African forest for the last 60 ka. Quat. Sci. Rev. 148, 101-114 (2016).

87. Lee, S.-Y., Chiang, J. C. H. \& Chang, P. Tropical Pacific response to continental ice sheet topography. Clim. Dyn. 44, 2429-2446 (2015).

88. deMenocal, P. B. et al. Abrupt onset and termination of the African Humid Period: Rapid climate responses to gradual insolation forcing. Quat. Sci. Rev. 19, 347-361 (2000).

89. Trauth, M. H. et al. Abrupt or gradual? Change point analysis of the late Pleistocene-Holocene climate record from Chew Bahir, southern Ethiopia. Quat. Res. 90, 1-10 (2018).

90. Eglinton, G. \& Hamilton, R. J. Leaf epicuticular waxes. Science 156, 1322-1335 (1967)

91. Konecky, B. L., Russell, J. \& Bijaksana, S. Glacial aridity in central Indonesia coeval with intensified monsoon circulation. Earth Planet. Sci. Lett. 437, 15-24 (2016).

92. Uno, K. T. et al. A Pleistocene palaeovegetation record from plant wax biomarkers from the Nachukui Formation, West Turkana, Kenya. Philos. Trans. R. Soc. Lond. B Biol. Sci. 371, 20150235 (2016).

93. Chikaraishi, Y., Naraoka, H. \& Poulson, S. R. Hydrogen and carbon isotopic fractionations of lipid biosynthesis among terrestrial (C3, C4 and CAM) and aquatic plants. Phytochemistry 65, 1369-1381 (2004).

94. Chikaraishi, Y. \& Naraoka, H. $\delta 13 \mathrm{C}$ and $\delta \mathrm{D}$ relationships among three $n$-alkyl compound classes ( $n$-alkanoic acid, $n$-alkane and $n$-alkanol) of terrestrial higher plants. Org. Geochem. 38, 198-215 (2007).

95. Paillard, D., Labeyrie, L. \& Yiou, P. AnalySeries 2.0: Macintosh program performs time-series analsyis. Eos Trans. Am. Geophys. Union 77, 379 (1996).

96. Foerster, V. et al. 46,000 years of alternating wet and dry phases on decadal to orbital timescales in the cradle of modern humans: The Chew Bahir project, southern Ethiopia. Clim. Past 10, 977-1023 (2014).

97. Bowen, G. J. \& Revenaugh, J. Interpolating the isotopic composition of modern meteoric precipitation. Water Resour. Res. 39, 10 (2003).

98. MathWorks. MATLAB Signal Processing Toolbox: User's Guide (The MathWorks, 2020).

99. Trauth, M. H. MATLAB Recipes for Earth Sciences (Springer, 2015). https://doi.org/10.1007/978-3-662-46244-7.

\section{Acknowledgements}

We wish to thank Laura Messier and Xiaonan Zhang for sample preparation assistance, Rafael Torozo, Marcelo Alexandre, and Ewerton Santos for laboratory assistance, and members of the Hominin Sites and Paleolakes Drilling Project for useful discussions. Initial core processing and sampling were conducted at the US National Lacustrine Core Facility (LacCore) at the University of Minnesota. This research was supported by the National Science Foundation (NSF) Grants EAR 1826938, EAR 1123942, EAR 1338553, and BCS 1241859, the International Continental Scientific Drilling Program (ICDP), and by the Deutsche Forschungsgemeinschaft (DFG, German Research Foundation) through the Priority Program SPP 1006 ICDP (SCHA 472/13 and /18, TR 419/8 and /10), the CRC 806 Research Project "Our way to Europe" Grant 57444011, and the UK Natural Environment Research Council (NERC) Grant NE/K014560/1. Data will be made available at the World Data Center-A for Paleoclimatology. This is publication \#50 of the Hominin Sites and Paleolakes Drilling Project.

\section{Author contributions}

R.L.L., J.M.R., E.J.P., I.S.C., and A.S.C. designed research; R.L.L. and E.J.P performed research; R.L.L. and J.M.R. analyzed data; R.L.L. and J.M.R. wrote the main manuscript text and all authors reviewed the manuscript.

\section{Competing interests}

The authors declare no competing interests.

\section{Additional information}

Supplementary Information The online version contains supplementary material available at https://doi.org/ 10.1038/s41598-022-06826-z.

Correspondence and requests for materials should be addressed to R.L.L.

Reprints and permissions information is available at www.nature.com/reprints.

Publisher's note Springer Nature remains neutral with regard to jurisdictional claims in published maps and institutional affiliations.

Open Access This article is licensed under a Creative Commons Attribution 4.0 International License, which permits use, sharing, adaptation, distribution and reproduction in any medium or format, as long as you give appropriate credit to the original author(s) and the source, provide a link to the Creative Commons licence, and indicate if changes were made. The images or other third party material in this article are included in the article's Creative Commons licence, unless indicated otherwise in a credit line to the material. If material is not included in the article's Creative Commons licence and your intended use is not permitted by statutory regulation or exceeds the permitted use, you will need to obtain permission directly from the copyright holder. To view a copy of this licence, visit http://creativecommons.org/licenses/by/4.0/.

(C) The Author(s) 2022 